Bangladesh J. Bot. 49(2): 223-228, 2020 (June)

\title{
EFFECTS OF PLANT GROWTH REGULATORS AND POTASSIUM ON GROWTH AND YIELD OF FINGER MILLET
}

\author{
R Sivakumar* and K Krishna Surendar \\ Department of Crop Physiology, Tamil Nadu Agricultural University, \\ Coimbatore, Tamil Nadu, India
}

Keywords: Growth regulators, Analytical traits, Yield, Finger millet, Rainfed condition

\begin{abstract}
Impact of plant growth regulators viz, benzyl amino purine (BAP - $50 \mathrm{ppm}$ ), brassinolide (BL - 0.5 $\mathrm{ppm})$, and nutrient like $\mathrm{KCl}(1 \%)$ alone and with combination on growth and growth analytical parameters, and yield of finger millet by foliar spray at panicle initiation stage under rainfed condition was studied in field experiment. The treatments including control, $\mathrm{KCl}, \mathrm{BAP}, \mathrm{BL}, \mathrm{KCl}+\mathrm{BAP}, \mathrm{KCl}+\mathrm{BL}, \mathrm{BAP}+\mathrm{BL}$ and $\mathrm{KCl}+\mathrm{BAP}+\mathrm{BL}$ and different growth and growth analytical parameters were estimated. Combination of $\mathrm{KCl}$, BAP and $\mathrm{BL}$ registered highest root length $(17.2 \mathrm{~cm})$, leaf area $\left(425.3 \mathrm{~cm}^{2}\right)$, leaf area index $(1.82)$ and leaf area duration (55.7 days) compared to other treatments. Higher specific leaf weight and crop growth rate were recorded by $\mathrm{KCl}+\mathrm{BAP}$, and $\mathrm{BAP}+\mathrm{BL}$, respectively. The highest grain yield of $22.5 \mathrm{Q} / \mathrm{ha}$ was recorded by $\mathrm{KCl}+\mathrm{BAP}+\mathrm{BL}$.
\end{abstract}

\section{Introduction}

Eleusine coracana L. Geartn called as finger millet and Ragi belonging to Poaceae and is one of the most important cereals in India after wheat and rice and ranks third in importance among millets in the world after pearl millet and foxtail millet (Upadhyaya et al. 2007). Finger millet is well adapted to heat and drought that prevails in marginal and degraded soils and has relatively better nutritional value. Because of its superior adaptability, it plays an important role in supporting marginal agriculture, such as that commonly practiced in semi-arid regions of India (Ravi et al. 2010). The high nutritive value compared to other cereals and grown in sterile soil makes finger millet as one of the salient crops among resource poor communities living in food insecure areas. Finger millet is a popular food among diabetic patients in the countries like India. Hence, finger millet is considered as 'poor man' and also 'rich man crop'.

The alarming increase of population growth, drought and erratic rainfall has been the main cause of food insecurity (AsnakeMekuriaw 2006). Drought is one of the most common environmental stresses that affects growth and development of plants. Even though, finger millet is drought tolerant crop, the yield potential is reduced when it is grown under rainfed condition. There is less chance of nutrients application through soil under rainfed condition. Hence, foliar application of nutrients, plant growth regulators and with consortia is possible to alleviate the drought effect and also enhance the productivity of crop under rainfed condition. Prabha $e t a l$. (2016) reported that the foliar application of plant growth regulators (PGRs) and nutrients twice at 50 and 70 days after sowing was found to give better yield and economic returns. Foliar application of potassium improved the drought tolerance, growth and yield components in wheat (Aown et al. 2012). Chang et al. (2016) reported that the exogenous application of cytokinin delayed leaf wilting under drought stress. Hence, the present study was undertaken to enhance the productivity of direct sown finger millet by using PGRs and nutrients under rainfed condition.

*Author for correspondence: <sivatnau14@gmail.com>. ${ }^{1}$ Crop Physiology Division, Regional Research Station-TNAU, Paiyur, India. 


\section{Materials and Methods}

The experiment was carried out at field number F1, Regional Research Station, Tamil Nadu Agricultural University, Paiyur by using finger millet variety Paiyur 2 seeds, sown directly to the field with the spacing of $22.5 \times 10 \mathrm{~cm}$ after the receipt of sufficient rainfall $(37 \mathrm{~mm})$. PGRs and nutrient solutions were prepared, separately, and treatments consisting of BAP (50 ppm), BL (0.5 ppm), $\mathrm{KCl}(1 \%), \mathrm{KCl}+\mathrm{BAP}, \mathrm{KCl}+\mathrm{BL}, \mathrm{BAP}+\mathrm{BL}$ and $\mathrm{KCl}+\mathrm{BAP}+\mathrm{BL}$ were applied as foliar spray at panicle initiation stage (60 days after sowing) and control was maintained with water spray. The experiment was carried out in RCBD with one variety imposed with eight treatments in three replications.

Plant height was measured from the ground level to the tip of the growing point. The plant was uprooted, and the root was taken with minimum damage and the length from the stem base to the root tip was measured. Number of leaves was determined by counting the leaves from the base to tip of the plant in each replication and mean value expressed in numbers. Leaf area per plant was measured by using leaf area meter (LICOR, Model LI 3000). Uprooted plant samples, after washing the root portion, were first shade dried and then oven dried at $80^{\circ} \mathrm{C}$ for $48 \mathrm{hrs}$. The dry weight of the leaf was recorded and expressed as g/plant.

Leaf area index (LAI) was calculated by employing the formula of Williams (1946) as follows. LAI $=$ Leaf area per plant/ground area occupied by the plant. Leaf area duration (LAD) was determined by using the formula of Power et al. (1967) as follows and expressed in days.

$$
\left.\mathrm{LAD}=\frac{\mathrm{L}_{1}+\mathrm{L}_{2}}{2} \mathrm{t}_{2}-\mathrm{t}_{1}\right)
$$

where, $\mathrm{L}_{1}=\mathrm{LAI}$ at first stage, $\mathrm{L}_{2}=\mathrm{LAI}$ at second stage, $\mathrm{t}_{2}-\mathrm{t}_{1}=$ Time interval in days

Specific leaf weight (SLW) was calculated by using the formula as suggested by Pearce $e t$ al. (1968) as follows. SLW = Leaf dry weight/leaf area. Crop growth rate (CGR) was calculated following the formula of Watson (1958).

$$
\mathrm{CGR}=\frac{\mathrm{W}_{2}-\mathrm{W}_{1}}{\mathrm{P}\left(\mathrm{t}_{2}-\mathrm{t}_{1}\right)}
$$

where, $\mathrm{W}_{2}$ and $\mathrm{W}_{1}=$ Whole plant dry weight at $\mathrm{t}_{2}$ and $\mathrm{t}_{1}$, respectively; $\mathrm{t}_{2}-\mathrm{t}_{1}=$ Time interval; $\mathrm{P}=$ Spacing in $\mathrm{m}^{2}$. The grain yield was recorded after harvest and expressed in terms of quintal per hectare. The data on various parameters were analyzed statistically as per the procedure suggested by Gomez and Gomez (1984).

\section{Results and Discussion}

Plant height is an important parameter that determines the growth and development of a plant. Combination of BAP + BL recorded highest plant height of $75.8 \mathrm{~cm}$ which is on par with $\mathrm{KCL}+$ $\mathrm{BAP}+\mathrm{BL}(74.4 \mathrm{~cm})$ and $\mathrm{KCl}+\mathrm{BL}(72.7 \mathrm{~cm})$ while compared to control $(58.6 \mathrm{~cm})$ at 120 days after sowing (Table 1). Foliar spray of PGRs (BAP + BL) increased the plant height up to $29.4 \%$ followed by $\mathrm{KCl}+\mathrm{BAP}+\mathrm{BL}(27 \%)$. The positive effect of brassinolide on plant height might be due to the induced synthesis of both IAA and GA and their cumulative action (Sengupta et al. 2011). Sivakumar and Jeya Priya (2017) reported that foliar spray of brassinolide increased the plant height up to $16.27 \%$ compared to control under stress condition. BAP generally synthesizes at root tip and induces shoot growth which results increasing plant height. Foliar spray of benzyl adenine increased plant height of Schefflera arboricola L. as $41.15 \%$ compared to control (Sardoei et al. 2014). The present result is in agreement with the earlier findings of Sardoei et al. (2014). In 
case of root length, combination of $\mathrm{KCL}+\mathrm{BAP}+\mathrm{BL}$ showed its superior value of $17.2 \mathrm{~cm}$ followed by KCL + BL $(16.2 \mathrm{~cm})$ and BAP + BL $(16.0 \mathrm{~cm})$ at 120 days after sowing (Table 1). Long root system is an advantageous under rainfed condition to support plant growth and extract water from deep soil layers. Root length increased up to $14.7 \%$ by the application of $\mathrm{KCl}+\mathrm{BAP}+$ BL compared to control. The increased root length by the application of potassium might be due to its action as compatible osmolyte which reduces the water potential of leaf ultimately inducing the root growth. Foliar application of $0.5 \mathrm{ppm}$ brassinolide increased the root length up to 16.27 per cent compared to control (Sivakumar and Jeya Priya 2017). Soad and AboHamad (2014) reported that the application of brassinolide causes a significant increase in root and shoot length of wheat and thereby counteracted the inhibitory effects of any adverse condition.

Table 1. Impact of PGRs and potassium on growth parameters of finger millet under rainfed condition.

\begin{tabular}{|c|c|c|c|c|c|c|c|c|}
\hline \multirow{2}{*}{ Treatments } & \multicolumn{2}{|c|}{ Plant height $(\mathrm{cm})$} & \multicolumn{2}{|c|}{ Root length $(\mathrm{cm})$} & \multicolumn{2}{|c|}{ Number of leaves } & \multicolumn{2}{|c|}{ Leaf area $\left(\mathrm{cm}^{2}\right)$} \\
\hline & 90 DAS & $120 \mathrm{DAS}$ & 90 DAS & $120 \mathrm{DAS}$ & 90 DAS & $120 \mathrm{DAS}$ & 90 DAS & 120 DAS \\
\hline Control & 57.1 & 58.6 & 14.8 & 15.0 & 12.0 & 10.3 & 363.6 & 338.5 \\
\hline $\mathrm{KCl}$ & 61.4 & 63.5 & 14.9 & 15.2 & 12.3 & 11.0 & 392.6 & 370.4 \\
\hline BAP & 61.3 & 64.0 & 14.4 & 14.8 & 13.0 & 12.3 & 400.1 & 392.0 \\
\hline BL & 65.9 & 66.8 & 15.4 & 15.6 & 12.7 & 11.7 & 396.7 & 390.5 \\
\hline $\mathrm{KCl}+\mathrm{BAP}$ & 63.5 & 64.7 & 14.7 & 15.3 & 13.0 & 12.0 & 404.4 & 393.2 \\
\hline $\mathrm{KCl}+\mathrm{BL}$ & 67.5 & 72.8 & 15.6 & 16.2 & 13.7 & 12.0 & 416.6 & 399.6 \\
\hline $\mathrm{BAP}+\mathrm{BL}$ & 69.0 & 75.8 & 15.2 & 16.0 & 14.0 & 13.0 & 421.2 & 407.9 \\
\hline $\mathrm{KCl}+\mathrm{BAP}+\mathrm{BL}$ & 71.6 & 74.4 & 17.1 & 17.2 & 14.3 & 13.3 & 425.3 & 409.6 \\
\hline SEd & 1.54 & 1.56 & 0.314 & 0.315 & 0.308 & 0.302 & 8.95 & 7.25 \\
\hline $\mathrm{CD}(\mathrm{p}=0.05)$ & 3.12 & 3.15 & 0.632 & 0.634 & 0.612 & 0.606 & 18.30 & 14.68 \\
\hline
\end{tabular}

The higher number of leaves (14.3) was registered by combination of PGRs (BAP + BL) and nutrient $(\mathrm{KCl})$. However, it is on par value with combination of PGRs (14.0) and $\mathrm{KCl}+\mathrm{BL}$ (13.7). The highest leaf area of $425.3 \mathrm{~cm}^{2}$ was found in the treatment $\mathrm{KCl}+\mathrm{BAP}+\mathrm{BL}$ which is at par with BAP + BL $\left(421.2 \mathrm{~cm}^{2}\right)$ and $\mathrm{KCl}+\mathrm{BL}\left(416.6 \mathrm{~cm}^{2}\right)$. Water sprayed control recorded least value of $363.6 \mathrm{~cm}^{2}$ leaf area at 90 days after sowing (Table 1). Foliar spray of $\mathrm{KCl}+\mathrm{BAP}+\mathrm{BL}$ showed its maximum effect in improving the leaf area by $16.9 \%$ followed by BAP + BL $(15.8 \%)$ and $\mathrm{KCl}+\mathrm{BL}(14.6 \%)$ compared to control at 90 DAS. Eskandari and Eskandari (2013) found that foliar application of 28 -homo brassinolide increased the number of leaves and leaf area compared to control. Thus, the present study corroborated with earlier findings.

LAI is one of the important factors influencing leaf net photosynthesis of the crop plants. It was enhanced by the foliar spray of $\mathrm{KCl}+\mathrm{BAP}+\mathrm{BL}$ (1.82) compared to control (1.50). PGRs with $\mathrm{KCl}$ recorded on par value with $\mathrm{BAP}+\mathrm{BL}(1.81)$ and $\mathrm{KCl}+\mathrm{BL}$ (1.78) (Table 2). Increased LAI up to $21.33 \%$ by the application of PGRs with $\mathrm{KCl}$ might be due to increased leaf area. Maintaining LAI under rainfed condition is necessary for carrying out current photosynthesis and ultimately yield. Sengupta et al. (2011) reported that the foliar application of brassinolide increased the LAI up to $49.38 \%$ in summer green gram. The positive role of BAP on leaf area and LAI might be due to its anti-senescence asset which maintains the leaf number, leaf area and LAI. LAD represents the functionality of the leaf over its life period and it is integration of LAI with time. The highest $\mathrm{LAD}$ was recorded by $\mathrm{KCL}+\mathrm{BAP}+\mathrm{BL}$ (55.7 days) which is at par with BAP + $\mathrm{BL}$ (55.3 days) and $\mathrm{KCl}+\mathrm{BL}$ (54.4 days) while least was recorded by control (46.8 days) (Table 
2). LAD parameter reflects the ability of plants to create and maintain the green leaf area for the longest time per unit land area. It is calculated as a conjunction of green leaf area size and it's duration (Hunkova et al. 2011).

Table 2. Impact of PGRs and potassium on LAI, LAD and yield of finger millet under rainfed condition.

\begin{tabular}{lccc}
\hline Treatments & LAI & LAD (Days) & Yield (Q/ha) \\
\hline Control & 1.50 & 46.8 & 18.9 \\
$\mathrm{KCl}$ & 1.65 & 50.9 & 20.0 \\
$\mathrm{BAP}$ & 1.74 & 52.8 & 19.5 \\
$\mathrm{BL}$ & 1.74 & 52.5 & 19.7 \\
$\mathrm{KCl}$ & 1.75 & 53.2 & 20.5 \\
$\mathrm{KCl}+\mathrm{BL}$ & 1.78 & 54.4 & 21.0 \\
$\mathrm{BAP}+\mathrm{BL}$ & 1.81 & 55.3 & 19.1 \\
$\mathrm{KCl}+\mathrm{BAP}+\mathrm{BL}$ & 1.82 & 55.7 & 22.5 \\
$\mathrm{SEd}$ & 0.036 & 1.02 & 0.451 \\
$\mathrm{CD}(\mathrm{p}=0.05)$ & 0.071 & 2.11 & 0.907 \\
\hline
\end{tabular}

Among the treatments, brassinolide alone and in combination with $\mathrm{BAP}$ and $\mathrm{KCl}$ showed at par value of LAD indicating its superior role on LAD. The increment of LAD by the application of BL is might be due to maintaining leaf area. This was the evidence that LAD and greenness of leaf are most important parameters connected with current photosynthesis and yield.

SLW is an indicator of the photo-assimilates production capacity of the plants per unit leaf area. The highest SLW of $2.55 \mathrm{mg} / \mathrm{cm}^{2}$ was recorded by $\mathrm{KCl}+\mathrm{BAP}$ followed by $\mathrm{KCl}+\mathrm{BAP}+$ $\mathrm{BL}$ (2.50) and $\mathrm{KCl}+\mathrm{BL}$ (2.4). Interestingly, BAP alone showed higher SLW (2.35) compared to $\mathrm{BL}$ alone (1.76) and $\mathrm{KCl}$ alone (1.8) (Fig. 1). On the other hand, brassinolide alone showed less SLW compared to $\mathrm{KCl}$ alone. However, the combination of $\mathrm{KCl}+\mathrm{BAP}+\mathrm{BL}$ showed the increment of 54.3\% SLW compared to control. Abou Aziz et al. (2011) registered that application of benzyl adenine significantly increased the SLW compared to the control. The increase in the SLW by benzyl adenine could be due to stimulating dry mass production through enhancement of cell division and chlorophyll accumulation which leads to higher photosynthetic activity and accumulation of dry matter.

CGR denotes dry matter accumulation per unit land area and unit time. Maintenance of CGR under rainfed situation is an essential growth analytical trait which decides the yield of crop plants. Combination of PGRs (BAP + BL) showed superior value of $17.0 \mathrm{~g} / \mathrm{m}^{2} /$ day followed by $\mathrm{KCl}+$ BAP + BL (16.9) and BL alone (16.5). Water sprayed control showed least value of CGR (15.5 $\mathrm{g} / \mathrm{m}^{2} /$ day) (Fig. 2). There was an increment of $9.7 \%$ CGR by the application of PGRs. The results indicated that the role of potassium and BAP on CGR is meager. However, the superior role of brassinolide on CGR might be due its synergistic role with IAA and GA.

Prakash et al. (2006) reported that application of brassinolide enhanced various physiological and biochemical processes ultimately leading to increased CGR and RGR in rice crops. Foliar application of $0.5 \mathrm{ppm}$ brassinolide increased the CGR in blackgram (Krishna Surendra et al. 2013). The present study confirmed the earlier findings.

The highest grain yield of $22.5 \mathrm{Q} / \mathrm{ha}$ was registered by combination of $\mathrm{KCl}+\mathrm{BAP}+\mathrm{BL}$ followed by $\mathrm{KCl}+\mathrm{BL}(21 \mathrm{Q} / \mathrm{ha})$ while the lowest was recorded by control $(18.9 \mathrm{Q} / \mathrm{ha})$. The grain yield was increased up to $19 \%$ by the application of PGRs with $\mathrm{KCl}$ under rainfed condition (Table 2). Combination of $\mathrm{KCl}+\mathrm{BAP}+\mathrm{BL}$ showed significantly superior yield compared to 
other treatments. The yield increment by brassinolide under rainfed might be due to the increment of plant height, leaf area, LAD and CGR which directly contribute to the photosynthesis and ultimately yield. Foliar application of brassinosteroid $(0.1 \mathrm{ppm})$ is advantageous in enhancing both growth and yield of pigeonpea (Sumathi et al. 2017). Raza et al. (2014) reported that the foliar application of potassium improved the yield attributes in wheat under water deficit condition. Application of brassinolide $(0.25 \mathrm{ppm})$ is an effective management practice to increase the yield of green gram crop grown under limited moisture condition (Sengupta et al. 2011).

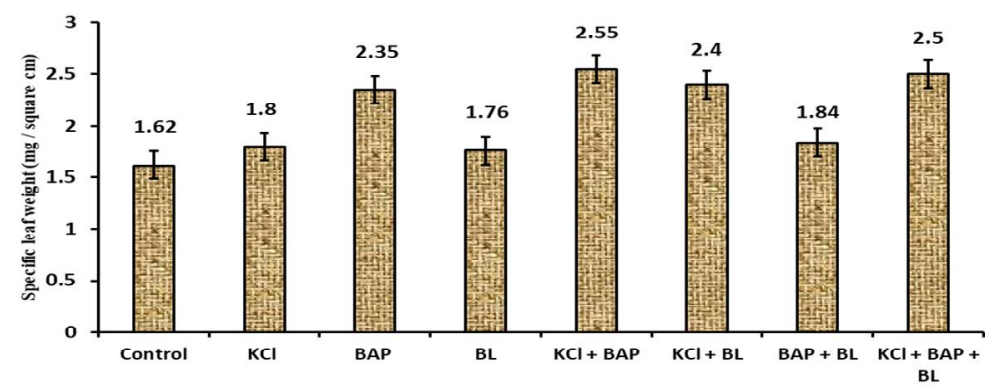

Fig. 1. Impact of PGRs and potassium on specific leaf weight of finger millet under rainfed condition.

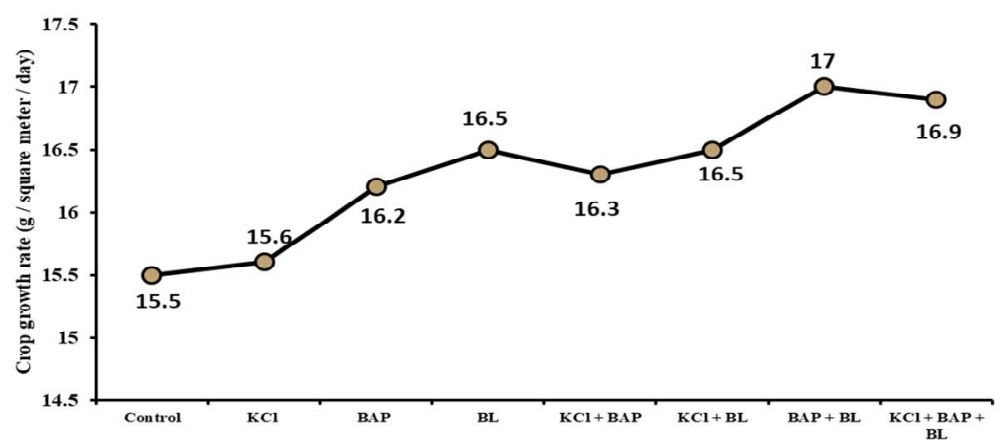

Fig. 2. Impact of PGRs and potassium on crop growth rate of finger millet under rainfed condition.

Foliar application of BL, BAP with $\mathrm{KCl}$ showed its supremacy for enhanced plant height, root length and leaf area in finger millet under rainfed condition. LAD and CGR were also improved by $\mathrm{BL}$ and $\mathrm{KCl}$. It is may be concluded that combination of $\mathrm{BL}+\mathrm{BAP}+\mathrm{KCl}$ has the ability to reduce the severity of the rainfed effect on finger millet and ultimately increased grain yield up to $19 \%$ and can be used as amelioration consortia under rainfed condition.

\section{References}

Abou Aziz AB, Hegazi ES, Yehia TA, Nabila E, Kassim S and Mahmoud TSM 2011. Growth, flowering and fruiting of Manzanillo Olive trees as affected by benzyl adenine. J. Hort. Sci. \& Ornamental Plants 3(3): 244-251.

Aown M, Raza S, Saleem MF, Anjum SA, Khaliq T and Wahid MA 2012. Foliar application of potassium under water deficit conditions improved the growth and yield of wheat (Triticum aestivum L.). J. of Animal \& Plant Sci. 22(2): 431-437.

AsnakeMekuriaw 2006. The role of land-use on impact of degradation in ShebelBerentawereda, Amhara national regional state, Ethiopia: A case study in kutkwatsekela catchment. M.Sc. Thesis. Addis Ababa University, Addis Ababa. 
Chang Z, Liu Y, Dong H, Teng K, Han L and Zhang X 2016. Effects of cytokinin and nitrogen on drought tolerance of creeping bent grass. PLoS One11(4): 1-19

Eskandari M and Eskandari A 2013. Effects of 28-homobrassinolide on growth, photosynthesis and essential oil content of Satureja khuzestanica. Inter. J. Plant Physiol. and Biochem. 5(3): 36-41.

Gomez KA and Gomez AA 1984. Statistical procedures for agricultural research. (2nd Ed.) John Wiley and sons, NewYork, USA, pp. 680.

Hunkova E, Zivcak M and Olsovska K 2011. Leaf area duration of oilseed rape (Brassica napus subsp. napus) varieties and hybrids and its relationship to selected growth and productivity parameters. J. Cen. Eur. Agric. 12(1): 1-15.

Krishna Surendar K, Vincent S, Mallika Vanagamudi and Vijayaraghavan H 2013. Physiology of Pgr's and nitrogen on crop growth rate, net assimilation rate, nitrate reductase activity and indole acetic acid oxidase activity of blackgram (Vigna Mungo L.). Genomics Appl. Biol. 4(3): 15-21.

Pearce RB, Brown RH and Balaster RE 1968. Photosynthesis of alfalfa leaves as influenced by environment. Crop Sci. 36: 677- 680

Power JE, Wills WO, Granes DL and Reichman GA 1967. Effect of soil temperature, phosphorus and plant age on growth analysis of barley. Agron. J. 59: 231-234.

Prabha V, Senthil A, Sritharan N and Boominathan P 2016. Effect of foliar application of plant growth regulators and nutrients on physiological traits of finger millet (Eleusine coracana). Res. on Crops 17(3): 483-488

Prakash M, Suganthi S, GokulakrishnanJ and Sabesan T 2006. Influence of 28-homobrassinolide on morphological, growth, biochemical and yield parameters of sesame. Crop Res. 32: 535-538.

Ravi SB, Swain DS and Parida NR 2010. Promoting nutritious millets for enhancing income and improved nutrition: A Case Study from Tamil Nadu and Orissa. M. S. Swaminathan Research Foundation, Chennai, Tamil Nadu, India.

Raza MAS, Saleem MF, Shah GM, Khan IH and Raza A 2014. Exogenous application of glycine betaine and potassium for improving water relations and grain yield of wheat under drought. J. Soil Sci. and Plant Nut. 14(2): 348-364.

Sardoei AS, Roein A, Shahadadi F, Sadeghi T and Mokhtari TS 2014. Endogenous gibberellic acid and benzyl adenine effects on stem elongation and leaf in Schefflera arboricola L. plants. Inter. J. Plant, Animal and Environ. Sci. 4(3): 431-437.

Sengupta K, Banik NC, Bhui S and Mitra S 2011. Effect of brassinolide on growth and yield of summer green gram crop. J. Crop and Weed 7(2): 152-154.

Sivakumar R and Jaya Priya S 2017. Effect of PGRs and nutrients on growth, physiological parameters and yield of Vigna mungo L. under saline stress. Inter. J. Plant \& Soil Sci. 18(6): 1-10.

Soad S and Abo Hamad A 2014. Effect of exogenous application of brassinolide on growth and metabolic activity of wheat seedlings under normal and salt stress conditions. Ann. Res. Rev. Bio. 4(24): 36873698

Sumathi A, Babu Rajendra V, Prasad and Mallika Vanangamudi 2017. Influence of plant growth regulators on yield and yield components in pigeon pea. Legume Res. 40(4): 1-7.

Upadhyaya HD, Gowda CLL and Reddy VG 2007. Morphological diversity in finger millet germplasm introduced from Southern and Eastern Africa. International Crops Research Institute for the Semi-Arid Tropics (ICRISAT), Patancheru 502 324, Andhra Pradesh, India.

Watson DJ 1958. Comparative physiological studies on the growth of field crops. Variation in net assimilation rate and leaf area between species and varieties and within and between years. Ann. Bot. 2: 41-76.

Williams SRF 1946. Methods of growth analysis. In: Plant photosynthetic production manual methods (Sestak, Z., J. Catasky and P. J. Jouris (eds). Drow, Jenk N.U. Publishers. The Hague, pp. 348-391. 